Review Paper

\title{
The Role of Resilience and Emotion Regulation in Psy- chological Distress of Hospital Staff During the COV- ID-19 Pandemic: A Systematic Review Study
}

Farzin Bagheri Sheykhangafshe $^{1}$ (D), Vahid Hajialiani² ${ }^{\text {(D) }}$, Jafar Hasani ${ }^{*}$ (i)

1. Department of Psychology, Faculty of Humanities, Tarbiat Modares University, Tehran, Iran

2. Department of Clinical Psychology, Faculty of Psychology and Educational Sciences, Kharazmi University, Tehran, Iran

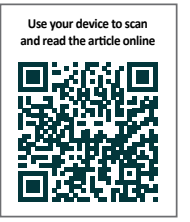

ditation Bagheri Sheykhangafshe F, Hajialiani V, Hasani J. The Role of Resilience and Emotion Regulation in Psychological Distress of Hospital Staff During the COVID-19 Pandemic: A Systematic Review Study. Journal of Research \& Health. 2021; 11(6):365-374. http://dx.doi.org/10.32598/JRH.11.6.1922.1

dol'http://dx.doi.org/10.32598/JRH.11.6.1922.1

\section{(i) (3)}

Article info:

Received: 10 Jul 2021

Accepted: 04 Sep 2021

Publish: 01 Dec 2021

\section{Keywords:}

Coronavirus 2019, Resilience, Emotion regulation, Psychological distress, Hospital staff

\section{ABSTRACT}

Background: During the COVID-2019 pandemic, the hospital staff was among the first to deal with this problem. Because of the high workload, the medical staff may experience psychological distress. In this regard, the present study was conducted to investigate the role of resilience and emotion regulation in managing the psychological distress of hospital staff during the COVID-2019 pandemic.

Methods: In the present study, we searched English databases, such as Google Scholar, PubMed, Scopus, ScienceDirect, and Iranian databases, such as Iranian databases of Scientific Information Database (SID), Iranian Publications (Magiran), and Iranian Medical Sciences Articles from February 2020 to July 2021 with using the keywords of "coronavirus 2019", "COVID-19", "depression", "anxiety", "stress", "resilience", "emotion regulation", "mental health", "medical staff", and "psychological distress". We also used the PRISMA(The Preferred Reporting Items for Systematic Reviews and Meta-analysis) checklist to review and control the quality of the articles.

Results: Studies have shown that resilience and emotion regulation strategies positively affect nurses, physicians, hospital staff, and medical students during the COVID-19 pandemic Good resilience and using adaptive emotion regulation strategies have reduced their anxiety, depression, insomnia, and fear, which results in increased psychological well-being during the COVID-19 pandemic.

Conclusion: Based on the reviewed articles, we found that COVID-19 can affect various aspects of the mental health of hospital staff. Given that COVID-19 is still mutating and it is impossible to predict a specific time for the end of this deadly virus, medical staff must receive the necessary training to improve resilience and emotion regulation strategies.

\section{* Corresponding Author:}

Jafar Hasani, PhD.

Address: Department of Clinical Psychology, Faculty of Psychology and Educational Sciences, Kharazmi University, Tehran, Iran.

Phone: +98 (88) 848938

E-mail: hasanimehr57@khu.ac.ir 


\section{Introduction}

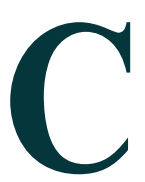

oronaviruses are single-stranded ribonucleic acid viruses belonging to the coronavirus family. Although primarily known as enzootic infections, they have evolved over the past few decades to infect humans [1]. The severity of coronavirus diseases ranges from the common cold to more serious illnesses, such as acute respiratory syndrome and the Middle East respiratory syndrome. The coronavirus 2019 first broke out on December 17, 2019, in Wuhan, China, and the World Health Organization declared it a pandemic on March 11, 2020 [2]. During the outbreak of COVID-19, the medical staff of hospitals was under a lot of pressure because of the heavy workload and dangerous work environment [3]. Harsh conditions can cause mental health problems, such as anxiety and depression. These problems affect the attention span, comprehension, and decision-making ability of the staff, which may impede their ability to treat patients with COVID-19. These mental problems may also have long-term effects on their physical and psychological health [4].

After facing natural disasters and unexpected events, medical staff usually demonstrate different psychological reactions [5]. During the COVID-19 outbreak, hospital staff worked around the clock, had no definitive treatment for the disease, and faced challenges they had not experienced before. For this reason, they may suffer from various mental injuries [6]. High workload, night shifts, lack of equipment, lack of familiarity and training in the face of disasters that kill the people who may not have normally passed away, the fear of being infected with COVID-19 and passing it on to family and relatives, witnessing the death of patients and prolonged separation from family can lead to psychological distress and increase the risk of posttraumatic stress in hospital staff $[7,8]$. Psychological distress is used to describe a condition in which a person becomes emotionally disturbed and loses his or her normal functioning levels. These conditions are usually characterized by symptoms of stress, anxiety, and depression [9]. Numerous factors, such as underlying disease, gender, age, and low education, can predict psychological distress in turbulent and stressful situations [10]. The prevalence of COVID-19, as well as strict measures and rules to control it, have caused changes in the lifestyle, social and occupational interactions of hospital staff, which increase the personnel's psychological distress [7]. Similarly, Elbay et al. [11], in a study on the medical staff of Turkish hospitals during the outbreak of COVID-19, concluded that $64 \%$ of the symptoms of the staff were depression, $51 \%$ anxiety, and $42 \%$ stress. Also, the findings of this study indicate a high correlation of female gender, low work experience, and being single with higher psychological distress in the medical staff.

In contrast, some studies have also reported that various interpersonal factors, such as resilience and emotion regulation, promote the mental health of medical staff during the COVID-19 pandemic $[12,13]$. Hospital staff uses different coping strategies in facing shocking, destructive, and stressful events [14]. Some people respond to stressful situations by giving in to psychological disorders, such as anxiety and depression, while others quickly adjust to the situation and resume their normal lives. This ability, which improves the mental state of individuals, is known in the positive psychological approach as resilience [15].

Resilience is the process of optimal adaptation in the face of difficulties, traumatic events, calamities, threats, or any tense situation. Resilient people return to an average level of performance after facing difficult life situations. Resilient people readily accept the realities of life and believe that life is meaningful [16]. Resilience refers to an individual's practical ability to adapt or cope with adverse conditions. This virtue may help maintain a person's mental health during a deadly pandemic [17]. The concept of resilience among the medical staff of hospitals facing natural disasters has drawn the attention of many researchers [18]. During the COVID-19 pandemic, resilience was also found to improve mental health [19] and reduce anxiety, stress, and burnout in hospital staff [20].

In this regard, Tam et al. [4] investigated the psychological distress of the medical staff during the COVID-19 outbreak with the mediating role of resilience. According to results, $38 \%$ of medical staff had psychological distress. But, people who received adequate social support and were highly resilient experienced less stress, depression, and anxiety. In another study, Luceño-Moreno et al. [8] examined posttraumatic stress, anxiety, depression, resilience, and burnout during the COVID-19 pandemic. In total, 56.6\% reported posttraumatic stress symptoms, $58.6 \%$ anxiety, $46 \%$ depression, and $41.1 \%$ burnout.

In contrast, people with good levels of resilience reported fewer psychological problems. Being a woman and working in the COVID-19 ward increase in psychological distress in the medical staff of hospitals. Sinichi et al. [21] also showed that nurses suffer from many psychological problems. Symptoms of stress were observed in $48.7 \%$, anxiety in $77.6 \%$, and depression in $60.5 \%$ of nurses. The most important strategy used in them was 
the emotion-focused type. There was a positive correlation between psychological disorders and emotion-based approaches, as well as a negative correlation between problem-based skills and the incidence of depression.

The ability to regulate emotion is critical to effective and successful performance in difficult and stressful situations, such as the COVID-19 pandemic [22]. Researchers have identified various cognitive and behavioral strategies for regulating emotions that can generally be divided into adaptive and incompatible strategies [23, 24].

Strategies such as acceptance, cognitive reassessment, and positively refocusing on planning or focusing on finding a solution to a problem are typically considered adaptive strategies, leading to reduced emotion and negative feelings [23]. In contrast, repression of emotions, self-blame, rumination, and catastrophizing are recognized as maladaptive emotion regulation strategies that exacerbate and prolong negative emotions [24]. In the COVID-19 pandemic, emotion regulation strategies also play an important role in treating depression, anxiety, and stress in medical staff [13]. Investigations conducted during the outbreak of COVID-19 have shown that people with self-blame, rumination, and rejection experience high levels of anxiety and depression $[25,26]$. In contrast, therapeutic staff who used adaptive cognitiveemotional regulation, such as positive reassessment and refocused on positive planning, had better mental and physical health [27]. In a similar study, Wang et al. [28] examined anxiety, depression, and cognitive emotion regulation in nurses during the COVID-19 outbreak. This study showed that $27.6 \%$ and $32.8 \%$ of nurses have symptoms of anxiety and depression, respectively. Also, low self-blame, lack of rumination, and positive acceptance decreased anxiety and depression in nurses. In another study, Zhu et al. [29] examined nurses' mental health and emotion regulation strategies during the COVID-19 outbreak. The results showed that 55\% had anxiety, and 56.4\% had depression. Also, 31.6\% reported simultaneous symptoms of anxiety and depression. Nurses who used negative emotion regulation strategies had lower mental health. Safa et al. [30] also reported that a significant number of nurses had severe posttraumatic stress. There was a significant difference between different age groups in terms of the depression absence scale and between individuals with different marital statuses in terms of pervasive memories subscales and inability to control emotions and total posttraumatic stress score.

Because the medical staff of the hospitals was at risk of developing COVID-19 from the very first days, they suffered from extensive psychological damage, such as posttraumatic stress, anxiety, depression, burnout, and insomnia. If these problems are not taken into account, they may create irreparable consequences for these people [31, 32]. On the other hand, more than a year after the outbreak of COVID-19, we are still witnessing the mutation of this deadly virus on a global scale, and a definite date for the post-corona era is inconceivable [33, 34]. Thus, it is necessary to seek solutions to improve the mental health of hospital nurses and doctors. For this purpose, the present review study was conducted to investigate the role of resilience and emotion regulation in the psychological distress of medical staff during the COVID-19 pandemic.

\section{Methods}

The present study is a systematic review study that, through PRISMA (The Preferred Reporting Items for Systematic Reviews and Meta-Analysis) [35] model, examined the research findings related to the role of resilience and emotion regulation on the psychological distress of the medical staff of hospitals during the COVID-19 pandemic. In the present study, using the keywords of "coronavirus 2019", "COVID-19", "depression", "anxiety", "stress", "resilience", "emotion regulation", "mental health", "medical staff”, and "psychological distress", we searched in English databases of Google Scholar, PubMed, Scopus, ScienceDirect, as well as Iranian databases of Scientific Information Database (SID) of Jahad Daneshgahi, Iranian Publications (Magiran) and Iranian Medical Sciences articles from February 2020 to July 2021. After collecting the articles, irrelevant and duplicate papers were removed by the researchers. In the next step, the full texts of the remaining articles were examined, and after removing the irrelevant items, the remaining articles were categorized and analyzed. Research articles were selected based on the inclusion criteria (relevance to the purpose of the research, having a structured research framework and publication in a valid journal) and exclusion criteria (unavailability of full text of the article, letter to the editor, and no abstract). The quality of articles was evaluated using the Gifford et al. criteria [36]. Based on the criteria provided for quantitative (6 criteria), qualitative (11 criteria), quasi-experimental ( 8 criteria), and experimental ( 7 criteria) studies, the articles were evaluated on a 2-point scale $(0$ and 1). Out of 593 articles related to the role of resilience and emotion regulation in the psychological distress of hospital staff during the COVID-19 pandemic, 30 completely related articles were included in the study. Then, they were studied thoroughly and accurately (Figure 1). 

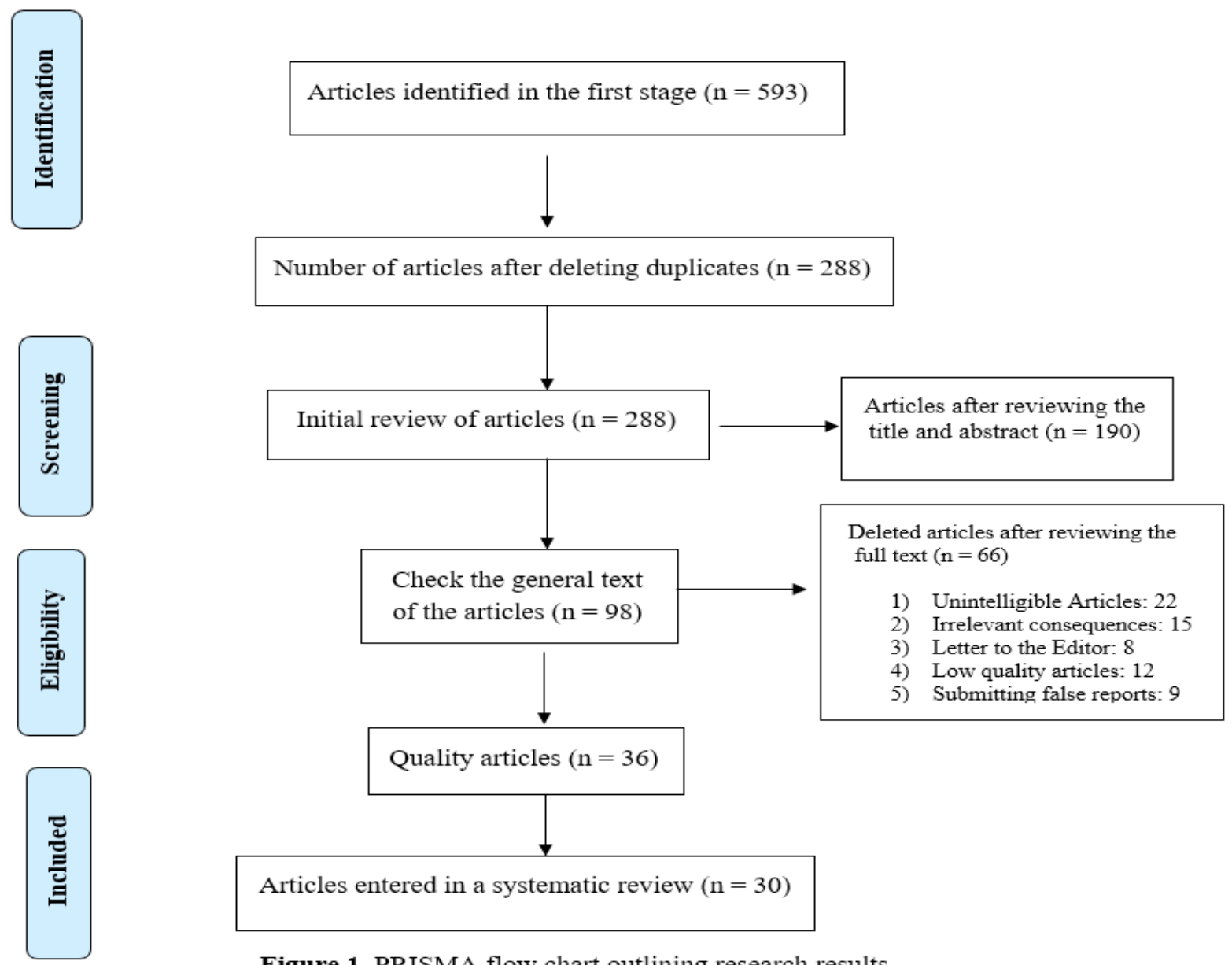

Figure 1. PRISMA flow chart outlining research results

Figure 1. Prisma flow chart outlining research results

\section{Results}

In this study, 30 qualified research articles in Persian and English were reviewed. Table 1 presents the findings from the reviewed articles on the role of resilience and emotion regulation in the psychological distress of hospital staff during the COVID-19 pandemic. Out of 593 articles related to the role of resilience and emotion regulation in the psychological distress of hospital staff during the COVID-19 pandemic, 30 articles with a total of 13902 samples were selected and reviewed based on the inclusion and exclusion criteria. The studies were collected from 16 countries: Iran, Italy, the Dominican Republic, China, Romania, Turkey, the United States, Nigeria, South Korea, Bahrain, Serbia, Indonesia, the United Kingdom, Portugal, Oman, and Spain. Of the 30 articles reviewed, 24 were quantitative articles, and one was a review article. Also, $36.6 \%$ and $63.4 \%$ of articles were published in 2020 and 2021, respectively.

Studies have shown that resilience and emotion regulation strategies during the outbreak of COVID-19 had positive effects on nurses, physicians, hospital staff, and medical students. Most studies have shown that good resilience and the use of adaptive emotion regulation strategies can reduce anxiety, depression, insomnia, fear, and rumination, which results in increased well-being and psychological health of hospital staff during the COVID-19 pandemic.

\section{Discussion}

This study aimed to investigate the role of resilience and emotion regulation in the psychological distress of hospital staff during the COVID-19 pandemic. The present study results showed that medical staff with high resilience performed better in the face of COVID-19 stress and anxiety and had good mental health [6-10].

In explaining these findings, it can be acknowledged that coping strategies help hospital staff when they face stressful and anxious issues, such as the outbreak of COVID-19 and the high volume of hospitalized patients, positive behaviors are not observed. show good coping styles and 
Table 1. Characteristics of the studies selected

\begin{tabular}{|c|c|c|c|c|c|}
\hline \multicolumn{2}{|r|}{ Authors [Ref.] } & Purposes & Sample & Country & Results \\
\hline 1 & Lorente et al. [3] & $\begin{array}{l}\text { Factors causing psychological dis- } \\
\text { tress of nurses during COVID-19 } \\
\text { pandemic with the mediating } \\
\text { role of resilience }\end{array}$ & 421 & Spain & $\begin{array}{l}\text { This study showed a positive correlation between } \\
\text { emotion-oriented coping strategies and psycho- } \\
\text { logical distress. Resilience and problem-solving } \\
\text { coping strategies also reduced nurses' depres- } \\
\text { sion, stress, and anxiety during the COVID-19. }\end{array}$ \\
\hline 2 & Tam et al. [4] & $\begin{array}{l}\text { Evaluation of psychological } \\
\text { distress of medical staff during } \\
\text { the COVID-19 pandemic with the } \\
\text { mediating role of resilience }\end{array}$ & 1029 & China & $\begin{array}{l}\text { According to this study, } 38 \% \text { of medical staff had } \\
\text { psychological distress. People who received ad- } \\
\text { equate social support and were highly resilient } \\
\text { experienced less stress, depression, and anxiety. }\end{array}$ \\
\hline 3 & Labrague [5] & $\begin{array}{l}\text { Evaluation of psychological } \\
\text { resilience, coping behaviors and } \\
\text { social support of medical staff } \\
\text { during the COVID-19 pandemic }\end{array}$ & 31 & Oman & $\begin{array}{l}\text { The study has shown that nurses and physicians } \\
\text { who enjoy high resilience, social support, and } \\
\text { positive coping behaviors during the COVID-19 } \\
\text { pandemic are less likely to experience anxiety } \\
\text { and stress caused by COVID-19. }\end{array}$ \\
\hline 4 & $\begin{array}{l}\text { Collantoni et } \\
\text { al. [6] }\end{array}$ & $\begin{array}{l}\text { Psychological distress, resilience, } \\
\text { and fear of COVID-19 in the } \\
\text { medical staff of hospitals }\end{array}$ & 996 & Italy & $\begin{array}{l}\text { Nurses reported more anxiety, stress, and in- } \\
\text { somnia than physicians and other hospital staff. } \\
\text { Also, being a woman, working in the COVID-19 } \\
\text { Ward, and fear of getting COVID-19 were some } \\
\text { of the factors that caused psychological distress. } \\
\text { Resilience also reduced psychological distress } \\
\text { and fear of getting COVID-19. }\end{array}$ \\
\hline 5 & Serrão et al. [7] & $\begin{array}{l}\text { Investigating the mediating } \\
\text { role of resilience in relation to } \\
\text { burnout and depression of medi- } \\
\text { cal staff during the COVID-19 } \\
\text { pandemic }\end{array}$ & 2008 & Portugal & $\begin{array}{l}\text { The study has shown that depression in medical } \\
\text { staff increases their burnout. In contrast, people } \\
\text { with psychological resilience cope better with } \\
\text { the situation and have less depression. }\end{array}$ \\
\hline 6 & $\begin{array}{l}\text { Luceño-Moreno } \\
\text { et al. [8] }\end{array}$ & $\begin{array}{l}\text { Evaluation of posttraumatic } \\
\text { stress, anxiety, depression, } \\
\text { resilience, and burnout of medi- } \\
\text { cal staff during the COVID-19 } \\
\text { pandemic. }\end{array}$ & 1422 & Spain & $\begin{array}{l}\text { In total, } 56.6 \% \text { of medical staff reported post- } \\
\text { traumatic stress symptoms, } 58.6 \% \text { reported } \\
\text { anxiety, } 46 \% \text { reported depression, and } 41.1 \% \\
\text { reported burnout. In contrast, people with good } \\
\text { levels of resilience have fewer psychological } \\
\text { problems. Being a woman and working in the } \\
\text { COVID-19 ward led to an increase in psychologi- } \\
\text { cal distress in the medical staff of hospitals. }\end{array}$ \\
\hline 7 & Huang et al. [10] & $\begin{array}{l}\text { Factors related to resilience } \\
\text { among hospital medical staff } \\
\text { during the COVID-19 pandemic. }\end{array}$ & 600 & China & $\begin{array}{l}\text { Based on the studies, gender, age, level of edu- } \\
\text { cation, protective equipment, stress, and anxiety } \\
\text { played a role in the level of resilience of individu- } \\
\text { als. For this purpose, it is necessary to take mea- } \\
\text { sures to increase resilience. }\end{array}$ \\
\hline 8 & $\begin{array}{c}\text { Roberts et al. } \\
\text { [12] }\end{array}$ & $\begin{array}{l}\text { Levels of depression, anxiety, } \\
\text { and resilience in respiratory } \\
\text { nurses during COVID-19 out- } \\
\text { breaks }\end{array}$ & 255 & England & $\begin{array}{l}\text { About } 17.2 \% \text { of nurses had high levels of depres- } \\
\text { sion and anxiety. Also, } 18.9 \% \text { suffered from low } \\
\text { resilience. Young and inexperienced nurses had } \\
\text { more depression and anxiety, which reduced } \\
\text { their resilience. }\end{array}$ \\
\hline 9 & Man et al. [13] & $\begin{array}{l}\text { Understanding illness and coping } \\
\text { with emotional distress during } \\
\text { the COVID-19 pandemic }\end{array}$ & 115 & Romania & $\begin{array}{l}\text { This study showed that medical staff experience } \\
\text { more stress and anxiety than in the past, which } \\
\text { eventually led to their understanding of the dis- } \\
\text { ease. Emotion regulation also helps people cope } \\
\text { with anxiety. }\end{array}$ \\
\hline 10 & Chang et al. [14] & $\begin{array}{l}\text { Investigating the role of religion } \\
\text { and psychological resilience in } \\
\text { the mental health of medical } \\
\text { staff during the COVID-19 }\end{array}$ & 458 & China & $\begin{array}{l}\text { About } 12.3 \% \text { of hospital staff suffered from psy- } \\
\text { chological distress, most of whom did not re- } \\
\text { ceive adequate social support. Religious people } \\
\text { with good resilience were also more resistant to } \\
\text { COVID-19 stress and anxiety. }\end{array}$ \\
\hline 11 & $\begin{array}{c}\text { Setiawati et al. } \\
{[15]}\end{array}$ & $\begin{array}{l}\text { Evaluation of resilience and } \\
\text { anxiety of medical staff during } \\
\text { the COVID-19 pandemic }\end{array}$ & 227 & Indonesia & $\begin{array}{l}33 \% \text { of the medical staff had state anxiety, and } \\
26.9 \% \text { had trait anxiety. The mean resilience } \\
\text { score was } 69 \text {, which had a direct negative cor- } \\
\text { relation with the level of anxiety. }\end{array}$ \\
\hline 12 & Ristić et al. [16] & $\begin{array}{l}\text { Levels of stress and resilience } \\
\text { in the medical staff during the } \\
\text { COVID-19 pandemic }\end{array}$ & 483 & Serbia & $\begin{array}{l}\text { Medical students and medical staff participated } \\
\text { in this study. About } 57.3 \%, 26.7 \% \text {, and } 15.9 \% \text { had } \\
\text { mild, moderate, and severe stress, which was } \\
\text { higher in medical students compared to medical } \\
\text { staff. Low fertility, femininity, and poor financial } \\
\text { status were also associated with stress levels. }\end{array}$ \\
\hline
\end{tabular}




\begin{tabular}{|c|c|c|c|c|c|}
\hline \multicolumn{2}{|r|}{ Authors [Ref.] } & Purposes & Sample & Country & Results \\
\hline 13 & $\begin{array}{c}\text { Aljehani et al. } \\
{[17]}\end{array}$ & $\begin{array}{l}\text { Evaluation of stress and psy- } \\
\text { chological resilience in surgical } \\
\text { residents during the COVID-19 } \\
\text { pandemic }\end{array}$ & 234 & Bahrain & $\begin{array}{l}\text { The mean age was } 28 \text { years, } 53.8 \% \text { were single, } \\
65.8 \% \text { were male, and } 50.4 \% \text { were placed in inten- } \\
\text { sive care units due to lack of human resources. Of } \\
\text { these, } 117 \text { had high stress and anxiety. The level } \\
\text { of education, being a man, activity in the intensive } \\
\text { care unit, and lack of equipment were significantly } \\
\text { associated with the level of stress and anxiety. }\end{array}$ \\
\hline 14 & Hong et al. [18] & $\begin{array}{l}\text { Resilience, work stress, and } \\
\text { depression of nurses during the } \\
\text { COVID-19 pandemic }\end{array}$ & 824 & $\begin{array}{l}\text { South } \\
\text { Korea }\end{array}$ & $\begin{array}{l}\text { Studies have shown that resilience was negative- } \\
\text { ly correlated with nurses' stress and depression. } \\
\text { Also, age, marital status, and work experience } \\
\text { showed a significant relationship with the level } \\
\text { of staff stress. }\end{array}$ \\
\hline 15 & Coco et al. [19] & $\begin{array}{l}\text { Psychological dimensions and } \\
\text { resilience of medical staff during } \\
\text { the COVID-19 pandemic }\end{array}$ & 152 & Italy & $\begin{array}{l}\text { The findings showed that demographic factors } \\
\text { could affect the level of stress and resilience of } \\
\text { individuals. Age, gender, marital status, level of } \\
\text { knowledge of individuals, work history, and ac- } \\
\text { tivity in the COVID-19 ward were involved in the } \\
\text { level of anxiety. Resilience as a mediating vari- } \\
\text { able also reduces stress and anxiety. }\end{array}$ \\
\hline 16 & $\begin{array}{c}\text { Yörük \& Güler } \\
\text { [20] }\end{array}$ & $\begin{array}{l}\text { Relationship between psycho- } \\
\text { logical resilience, burnout, stress, } \\
\text { and depression in nurses and } \\
\text { midwives during the COVID-19 } \\
\text { pandemic }\end{array}$ & 337 & Turkey & $\begin{array}{l}\text { The results showed a } 31.8 \% \text { prevalence of de- } \\
\text { pression in nurses and midwives. The rate of } \\
\text { midwives' depression was almost twice that of } \\
\text { nurses. Stress levels lead to increased burnout } \\
\text { and depression in nurses and midwives. In con- } \\
\text { trast, resilience could significantly improve the } \\
\text { mental health of medical staff. }\end{array}$ \\
\hline 17 & Sinichi et al. [21] & $\begin{array}{l}\text { Psychological symptoms and } \\
\text { coping strategies of nurses car- } \\
\text { ing for patients with COVID-19 } \\
\text { pneumonia }\end{array}$ & 67 & Iran & $\begin{array}{l}\text { The findings showed that nurses suffer from } \\
\text { many psychological problems. Symptoms of } \\
\text { stress were observed in } 48.7 \% \text {, anxiety in } 77.6 \% \text {, } \\
\text { and depression in } 60.5 \% \text { of nurses. The most im- } \\
\text { portant strategy used in them was the emotion- } \\
\text { focused type. There was a positive correlation } \\
\text { between psychological disorders and emotion- } \\
\text { based approaches, as well as a negative correla- } \\
\text { tion between problem-based skills and the inci- } \\
\text { dence of depression. }\end{array}$ \\
\hline 18 & $\begin{array}{c}\text { Söğütlü et al. } \\
\text { [26] }\end{array}$ & $\begin{array}{l}\text { The relationship between anxi- } \\
\text { ety, anger, sleep, and difficulty } \\
\text { in regulating emotion during the } \\
\text { COVID-19 pandemic }\end{array}$ & 406 & Turkey & $\begin{array}{l}\text { The level of anxiety was } 50.5 \% \text {, anger was } 34.8 \% \text {, } \\
\text { insomnia was } 35.4 \% \text {, and difficulty in regulating } \\
\text { emotion was } 36.1 \% \text {. The results also showed } \\
\text { that people who have difficulty regulating emo- } \\
\text { tion have more anxiety and anger, which leads to } \\
\text { disturbed sleep patterns. }\end{array}$ \\
\hline 19 & $\begin{array}{c}\text { Garcia-Batista et } \\
\text { al. [27] }\end{array}$ & $\begin{array}{l}\text { The mediating role of emotion } \\
\text { regulation on medical staff stress } \\
\text { during the COVID-19 pandemic }\end{array}$ & 155 & $\begin{array}{l}\text { Do- } \\
\text { minican } \\
\text { Republic }\end{array}$ & $\begin{array}{l}\text { This study showed that people with cognitive } \\
\text { bias experienced more COVID-19 anxiety. Ca- } \\
\text { tastrophe and rumination also led to increased } \\
\text { coronavirus stress and anxiety. }\end{array}$ \\
\hline 20 & Wang et al. [28] & $\begin{array}{c}\text { Evaluation of anxiety, depression } \\
\text { and cognitive emotion regulation } \\
\text { in nurses during the COVID-19 } \\
\text { pandemic }\end{array}$ & 586 & China & $\begin{array}{l}\text { Findings of this study showed that } 27.6 \% \text { and } \\
32.8 \% \text { of nurses have symptoms of anxiety and } \\
\text { depression. Also, low self-blame, lack of rumina- } \\
\text { tion, and positive acceptance led to decreased } \\
\text { anxiety and depression in nurses. }\end{array}$ \\
\hline 21 & Zhu et al. [29] & $\begin{array}{l}\text { Assessing mental health and } \\
\text { emotion regulation strategies } \\
\text { during the COVID-19 pandemic }\end{array}$ & 342 & China & $\begin{array}{l}\text { About } 55 \% \text { had anxiety, and } 56.4 \% \text { had depres- } \\
\text { sion. Also, } 31.6 \% \text { reported simultaneous symp- } \\
\text { toms of anxiety and depression. Nurses who } \\
\text { used negative emotion regulation strategies had } \\
\text { lower mental health. }\end{array}$ \\
\hline 22 & Safa et al. [30] & $\begin{array}{l}\text { Evaluation of posttraumatic } \\
\text { stress disorder in nursing staff } \\
\text { involved in the care of patients } \\
\text { with COVID-19 }\end{array}$ & 311 & Iran & $\begin{array}{l}\text { According to studies, a significant number of } \\
\text { nurses had severe posttraumatic stress. There } \\
\text { was a significant difference between different } \\
\text { age groups in the depression absence subscale } \\
\text { and between individuals with different marital } \\
\text { statuses, in the pervasive memories subscales } \\
\text { and inability to control emotions and total post- } \\
\text { traumatic stress score. }\end{array}$ \\
\hline
\end{tabular}




\begin{tabular}{|c|c|c|c|c|c|}
\hline \multicolumn{2}{|c|}{ Authors [Ref.] } & Purposes & \multirow{2}{*}{$\begin{array}{c}\text { Sample } \\
200\end{array}$} & \multirow{2}{*}{$\begin{array}{l}\text { Country } \\
\text { Italy }\end{array}$} & \multirow{2}{*}{$\begin{array}{l}\text { Results } \\
\text { According to the results, men scored higher in } \\
\text { mindfulness and emotion regulation. There was } \\
\text { also a significant difference in terms of gender, } \\
\text { age, work experience, and activity in the coro- } \\
\text { navirus ward. }\end{array}$} \\
\hline 23 & Vitale et al. [31] & $\begin{array}{l}\text { A survey of mindfulness and } \\
\text { emotion regulation in nurses } \\
\text { during the COVID-19 outbreak }\end{array}$ & & & \\
\hline 24 & $\begin{array}{c}\text { Croghan et al. } \\
\text { [32] }\end{array}$ & $\begin{array}{c}\text { Evaluation of resilience, stress, } \\
\text { and coping strategy of medi- } \\
\text { cal staff during the COVID-19 } \\
\text { outbreak }\end{array}$ & 302 & The USA & $\begin{array}{l}\text { Nurses, physicians, service staff, and administrative } \\
\text { and educational staff of the hospital participated } \\
\text { in this study. The study has shown high levels of } \\
\text { stress in young nurses. Resilience and problem- } \\
\text { oriented coping strategies also reduce stress. }\end{array}$ \\
\hline 25 & Sirati et al. [33] & $\begin{array}{l}\text { Perceived stress of medical and } \\
\text { non-medical staff in the face of } \\
\text { the pandemic of COVID-19 }\end{array}$ & 528 & Iran & $\begin{array}{l}\text { About } 90.2 \% \text { of people had moderate job stress, } \\
\text { and } 4.2 \% \text { had severe stress. The level of stress in } \\
\text { students was higher than in permanent and con- } \\
\text { tract employees. Also, women had more stress } \\
\text { than men, people with medication, people with- } \\
\text { out medication, and people with medical occu- } \\
\text { pations more than non-medical occupations. }\end{array}$ \\
\hline 26 & $\begin{array}{c}\text { Sarboozi et al. } \\
{[34]}\end{array}$ & $\begin{array}{c}\text { Nurses' depression, stress, } \\
\text { and anxiety in the COVID-19 } \\
\text { pandemic }\end{array}$ & 125 & Iran & $\begin{array}{l}\text { The study showed that nurses had moderate } \\
\text { psychological distress. Nurses' depression and } \\
\text { anxiety were also significantly associated with } \\
\text { age, employment status, and satisfaction with } \\
\text { personal protective equipment. }\end{array}$ \\
\hline 27 & $\begin{array}{l}\text { Rahmanian et } \\
\text { al. [37] }\end{array}$ & $\begin{array}{l}\text { Comparison of anxiety in medical } \\
\text { and non-medical staff of Jahrom } \\
\text { City in the face of COVID-19 }\end{array}$ & 402 & Iran & $\begin{array}{l}\text { The mean score of psychological symptoms of } \\
\text { the clinical staff was higher than the adminis- } \\
\text { trative staff. Also, the average score of physical } \\
\text { symptoms of the clinical staff was higher than } \\
\text { the administrative staff. There was a significant } \\
\text { difference between the clinical and administra- } \\
\text { tive staff in terms of mean anxiety. }\end{array}$ \\
\hline 28 & $\begin{array}{l}\text { Olashore et al. } \\
\qquad[38]\end{array}$ & $\begin{array}{c}\text { Evaluation of resilience, social } \\
\text { support, and anxiety of medi- } \\
\text { cal staff during the COVID-19 } \\
\text { outbreak }\end{array}$ & 373 & Nigeria & $\begin{array}{l}\text { The mean age was } 38 \text { years, of which } 65 \% \text { were } \\
\text { women, and } 57.6 \% \text { were nurses. About } 13 \% \text { of } \\
\text { people reported high anxiety. Also, the level of } \\
\text { resilience and social support was directly related } \\
\text { to people's anxiety levels. }\end{array}$ \\
\hline 29 & $\begin{array}{c}\text { Schierberl et al. } \\
\text { [39] }\end{array}$ & $\begin{array}{c}\text { The role of resilience and social } \\
\text { support on nurses' psychological } \\
\text { symptoms during the COVID-19 } \\
\text { outbreak }\end{array}$ & 312 & The USA & $\begin{array}{l}\text { The study has shown that nurses working in the } \\
\text { COVID-19 ward were more fearful and anxious. } \\
\text { Resilience and social support also reduced nurs- } \\
\text { es' anxiety and fear of COVID-19. }\end{array}$ \\
\hline 30 & $\begin{array}{l}\text { Di Giuseppe et } \\
\text { al. [40] }\end{array}$ & $\begin{array}{l}\text { Stress, burnout, and resilience } \\
\text { of medical staff during the CO- } \\
\text { VID-19 pandemic }\end{array}$ & 223 & Italy & $\begin{array}{l}\text { The medical staff working in the COVID-19 unit } \\
\text { experienced more stress and depression, and } \\
\text { more burnout. Stress and burnout were also as- } \\
\text { sociated with younger age and work history, be- } \\
\text { ing a woman, lack of protective equipment, and } \\
\text { activity in the coronavirus ward. }\end{array}$ \\
\hline
\end{tabular}

MRA

have more flexibility [4]. This ability helps nurses and physicians to accept existing conditions and perform at their best [8]. In contrast, low resilience leads to anxiety, stress, and burnout in hospital staff, result in reduced efficiency of services provided by hospital staff. Because resilience includes positive patterns of adaptation to hardships and difficulties over time, nurses and physicians with good resilience are expected to show better flexibility over time [12]. In other words, people with good resilience endure hardships, cope better with threatening situations, cope more effectively with stress and problems, and have a greater capacity to respond to life stressors and cope with everyday problems [17]. This ability causes hospital staff to adapt better to the anxious conditions (such as hospital overcrowding, equipment shortages, and medication) created by the COVID-19 pandemic [3]. In other words, the dimensions of resilience, such as personal competence, trust in instincts, positive acceptance of change, self-confidence, control, and spiritual impact when in stressful and difficult situations, help people to show the necessary flexibility, adapt to the current situation and use effective coping strategies better [14-20].

On the other hand, the findings showed that medical staff who used adaptive emotion regulation strategies, such as positive reassessment and refocusing on planning, positively coped with COVID-19 anxiety and stress. In contrast, the use of maladaptive emotion regulation strategies, such as catastrophe, rumination, and blaming others, negatively aggravates psychological disorders during the coronavirus 2019 pandemic. 
Explaining these findings, it can be acknowledged that people who manage and control their emotions during the COVID-19 outbreak have better mental health. When a person is faced with an emotional situation, feeling good and optimistic is not enough to control the emotion, but he needs to have the best cognitive function in these situations. In regulating emotion, an optimal interaction of cognition and emotion is required to deal with adverse conditions because people interpret every stimulus and situation they encounter, and cognitive interpretations determine people's reactions [29]. For this reason, people who use negative and weak cognitive styles, such as rumination, catastrophizing, and self-blame during the COVID-19 pandemic are more vulnerable to emotional problems than others [27]. In other words, people who could not properly manage their emotions in the face of stress caused by COVID-19 show more stress, depression, and anxiety. When people with high anxiety symptoms have more difficulty regulating their emotional functions, they are less able to recognize and accept their emotions and are more likely to show negative emotions in ambiguous emotional situations [26-31].

\section{Conclusion}

The present study results showed that resilience and emotion regulation play an important role in reducing depression, anxiety, and stress of hospital staff during the COVID-19 pandemic. People with high resilience are well aware of the situation and do their best to accept it and show their best performance. Emotion regulation also allows nurses and physicians to manage and control their emotions. This strategy prevents them from engaging in negative emotions and helps them show their best performance. In this regard, it is suggested to use appropriate psychological services in hospitals to promote the mental health of nurses and physicians.

One of the limitations of the present review study is the unavailability of the full text of some articles, which led to the non-inclusion of these articles in the review process. Also, due to the filtering of some scientific databases, researchers could not access them. In addition, some studies were descriptive and should be cautious in generalizing their results. In this regard, it is suggested that descriptive studies be conducted on the role of resilience and emotion regulation in promoting the mental health of nurses and medical staff of hospitals during the COVID-19 outbreak in the country. These studies improve the physical and psychological function of medical staff in Iran.

\section{Ethical Considerations}

\section{Compliance with ethical guidelines}

Ethical principles in writing the article have been observed according to the instructions of the National Ethics Committee and the COPE regulations.

\section{Funding}

The present study was self-funded.

Authors' contributions

All authors equally contributed to preparing this article.

\section{Conflict of interest}

The authors declared no conflict of interest.

\section{References}

[1] Fung TS, Liu DX. Human coronavirus: Host-pathogen interaction. Annual Review of Microbiology. 2019; 73:529-57. [DOI:10.1146/annurev-micro-020518-115759] [PMID]

[2] Cucinotta D, Vanelli M. Who declares covid-19 a Pandemic. Acta Biomedica. 2020; 91(1):157-60. [DOI:10.23750/abm. v91i1.9397] [PMID] [PMCID]

[3] Lorente L, Vera M, Peiró T. Nurses' stressors and psychological distress during the covid-19 pandemic: The mediating role of coping and resilience. Journal of Advanced Nursing. 2021; 77(3):1335-44. [DOI:10.1111/jan.14695] [PMID][PMCID]

[4] Tam CC, Sun S, Yang X, Li X, Zhou Y, Shen Z. Psychological distress among hiv healthcare providers during the covid-19 pandemic in China: Mediating roles of institutional support and resilience. AIDS and Behavior. 2021; 25(1):9-17. [DOI:10.1007/s10461-020-03068-w] [PMID] [PMCID]

[5] Labrague LJ. Psychological resilience, coping behaviours and social support among health care workers during the covid-19 pandemic: A systematic review of quantitative studies. Journal of Nursing Management. 2021; 29(7):1893-1905 [DOI:10.1111/jonm.13336] [PMID] [PMCID]

[6] Collantoni E, Saieva AM, Meregalli V, Girotto C, Carretta G, Boemo DG, et al. Psychological distress, fear of covid-19, and resilient coping abilities among healthcare workers in a tertiary first-line hospital during the coronavirus pandemic. Journal of Clinical Medicine. 2021; 10(7):1465. [DOI:10.3390/ jcm10071465] [PMID][PMCID]

[7] Serrão C, Duarte I, Castro L, Teixeira A. Burnout and depression in portuguese healthcare workers during the covid-19 pandemic-the mediating role of psychological resilience. International journal of environmental research and public health 2021;18(2):636. [DOI:10.3390/ijerph18020636] [PMID] [PMCID] 
[8] Luceño-Moreno L, Talavera-Velasco B, García-Albuerne Y, Martín-García J. Symptoms of posttraumatic stress, anxiety, depression, levels of resilience and burnout in Spanish health personnel during the covid-19 pandemic. International Journal of Environmental Research and Public Health. 2020; 17(15):5514. [DOI:10.3390/ijerph17155514] [PMID] [PMCID]

[9] Bagheri Sheykhangafshe F, Tajbakhsh K, Abolghasemi A. [Comparison of covid-19 anxiety, coping styles and health anxiety in athletic and non-athletic students (Persian)]. Sport Psychology Studies (ie, mutaleat ravanshenasi varzeshi). 2020; 9(32):283-306. [DOI:10.22089/spsyj.2020.9377.2027]

[10] Huang L, Wang Y, Liu J, Ye P, Cheng B, Xu H, et al. Factors associated with resilience among medical staff in radiology departments during the outbreak of 2019 novel coronavirus disease (covid-19): A cross-sectional study. Medical Science Monitor. 2020; 26:e925669. [DOI:10.12659/MSM.925669] [PMID] [PMCID]

[11] Elbay RY, Kurtulmuş A, Arpacıoğlu S, Karadere E. Depression, anxiety, stress levels of physicians and associated factors in covid-19 pandemics. Psychiatry Research. 2020; 290:113130. [DOI:10.1016/j.psychres.2020.113130] [PMID] [PMCID]

[12] Roberts NJ, McAloney-Kocaman K, Lippiett K, Ray E, Welch L, Kelly C. Levels of resilience, anxiety and depression in nurses working in respiratory clinical areas during the covid pandemic. Respiratory Medicine. 2021; 176:106219. [DOI:10.1016/j. rmed.2020.106219] [PMID] [PMCID]

[13] Man MA, Toma C, Motoc NS, Necrelescu OL, Bondor CI Chis $\mathrm{AF}$, et al. Disease perception and coping with emotional distress during covid-19 pandemic: A survey among medical staff. International Journal of Environmental Research and Public Health. 2020; 17(13):4899. [DOI:10.3390/ ijerph17134899] [PMID] [PMCID]

[14] Chang MC, Chen PF, Lee TH, Lin CC, Chiang KT, Tsai MF, et $\mathrm{al}$. The effect of religion on psychological resilience in healthcare workers during the coronavirus disease 2019 pandemic. Frontiers in Psychology. 2021; 12:628894. [DOI:10.3389/fpsyg.2021.628894] [PMID] [PMCID]

[15] Setiawati Y, Wahyuhadi J, Joestandari F, Maramis MM, Atika A. Anxiety and resilience of healthcare workers during covid-19 pandemic in indonesia. Journal of Multidisciplinary Healthcare. 2021; 14:1-8. [DOI:10.2147/JMDH.S276655] [PMID] [PMCID]

[16] Ignjatović Ristić D, Hinić D, Banković D, Kočović A, Ristić I, Rosić G,et al. Levels of stress and resilience related to the covid-19 pandemic among academic medical staff in Serbia. Psychiatry and Clinical Neurosciences. 2020; 74(11):604-5. [DOI:10.1111/ pcn.13124] [PMID] [PMCID]

[17] Aljehani YM, Othman SA, Telmesani NK, Alghamdi RA, AlBuainain HM, Alghamdi ZM, et al. [Stress and psychological resilience among general surgery residents during covid-19 pandemic (Persian)]. Saudi Medical Journal. 2020; 41(12):1344-9. [DOI:10.15537/smj.2020.12.25577] [PMID] [PMCID]

[18] Hong Y, Lee J, Lee HJ, Kim K, Cho IK, Ahn MH, et al. Resilience and work-related stress may affect depressive symptoms in nursing professionals during the covid-19 pandemic era. Psychiatry Investigation. 2021; 18(4):357-63. [DOI:10.30773/pi.2021.0019] [PMID] [PMCID]

[19] Coco M, Guerrera CS, Santisi G, Riggio F, Grasso R, Di Corrado $\mathrm{D}$, et al T. Psychosocial impact and role of resilience on healthcare workers during covid-19 pandemic. Sustainability. 2021; 13(13):7096. [Doi:10.3390/su13137096]
[20] Yörük S, Güler D. The relationship between psychological resilience, burnout, stress, and sociodemographic factors with depression in nurses and midwives during the covid-19 pandemic: A cross-sectional study in Turkey. Perspectives In Psychiatric Care. 2021; 57(1):390-8. [DOI:10.1111/ppc.12659] [PMID]

[21] Sinichi F, Faridhosseini F, Hajebi Khaniki S, Chalakinia N, Saadati Z, Tara F. [Psychological symptoms and coping strategies of nurses caring for patients with covid-19 pneumonia (Persian)]. Journal of Fundamentals of Mental Health. 2020; 22(6):481-89. [DOI:10.22038/jfmh.2020.17817]

[22] Garnefski N, Kraaij V. Cognitive emotion regulation questionnaire-development of a short 18-item version (CERQ-short). Personality and Individual Differences. 2006; 41(6):1045-53. [DOI:10.1016/j.paid.2006.04.010]

[23] Gross JJ, John OP. Individual differences in two emotion regulation processes: Implications for affect, relationships, and well-being. Journal of Personality and Social Psychology. 2003; 85(2):348-62. [DOI:10.1037/0022-3514.85.2.348] [PMID]

[24] Sheppes G, Suri G, Gross JJ. Emotion regulation and psychopathology. Annual review of clinical psychology. 2015; 11:379-405. [DOI:10.1146/annurev-clinpsy-032814-112739] [PMID]

[25] Bagheri Sheykhangafshe F, Esmaeilinasab M. [Psychological implications of coronavirus 2019 (covid-19) outbreak in chronic diseases Patients: A systematic review article (Persian)]. Chronic Diseases Journal. 2021; 9(3). [DOI:10.22122/cdj.v9i3.629]

[26] Söğütlü Y, Söğütlü L, Göktaş Sş. Relationship of covid-19 pandemic with anxiety, anger, sleep and emotion regulation in healthcare professionals. Journal of Contemporary Medicine. 2021; 11(1):41-9. [DOI:10.16899/jcm.804329] https://dergipark. org.tr/en/pub/jcm/issue/57927/804329

[27] García-Batista ZE, Guerra-Peña K, Nouri Kandany V, Marte MI, Garrido LE, Cantisano-Guzmán LM, et al. Covid-19 pandemic and health worker stress: The mediating effect of emotional regulation. PLoS One. 2021; 16(11):e0259013. [DOI:10.1371/ journal.pone.0259013] [PMID] [PMCID]

[28] Wang QQ, Fang YY, Huang HL, Lv WJ, Wang XX, Yang TT, et al. Anxiety, depression and cognitive emotion regulation strategies in Chinese nurses during the covid-19 outbreak. Journal of Nursing Management. 2021; 29(5):1263-74. [DOI:10.1111/ jonm.13265] [PMID] [PMCID]

[29] Zhu Y, Wang H, Wang A. An evaluation of mental health and emotion regulation experienced by undergraduate nursing students in China during the covid-19 pandemic: A cross-sectional study. International Journal of Mental Health Nursing. 2021; 30(5):1160-9. [DOI:10.1111/inm.12867] [PMID] [PMCID]

[30] Safa M, Ismaili Dolabi Nejad Sh, Qasem Boroujerdi F, Hajizadeh F, Mirabzadeh Ardakani B. [Incidence of post-traumatic stress disorder after covid-19 among medical staff of Masih Daneshvari hospital (Persian)]. Journal of Medical Council of Iran. 2020; 38(1):27-33. http://jmciri.ir/article-1-2980-en.html

[31] Vitale E. The mindfulness and the emotional regulation skills in Italian nurses during the covid-19 pandemic: A descriptive survey-correlational study. Journal of Holistic Nursing. 2021; 39(4):345-55. [DOI:10.1177/08980101211015804] [PMID]

[32] Croghan IT, Chesak SS, Adusumalli J, Fischer KM, Beck EW, Patel SR, et al. Stress, resilience, and coping of healthcare workers during the covid-19 pandemic. Journal of Primary Care \& Community Health. 2021; 12:21501327211008448. [DOI:10.1177/21501327211008448] [PMID] [PMCID] 
[33] Sirati Nir M, Karimi L, Khalili R. [The perceived stress level of health care and non-health care in exposed to covid-19 pandemic (Persian)]. Iranian Journal of Psychiatry \& Clinical Psychology. 2020; 26(3):294-305. [DOI:10.32598/ijpcp.26.3405.1]

[34] Sarboozi Hosein Abadi T, Askari M, Miri K, Namazi Nia M. [Depression, stress and anxiety of nurses in covid-19 pandemic in Nohe-Dey hospital in Torbat-e-Heydariyeh city, Iran (Persian)]. Journal of Military Medicine. 2020; 22(6):526-33. [DOI:10.30491/JMM.22.6.526]

[35] Moher D, Liberati A, Tetzlaff J, Altman DG; Prisma Group. Preferred reporting items for systematic reviews and metaanalyses: The PRISMA statement. International Journal of Surgery. 2010; 8(5):336-41. [DOI:10.1016/j.ijsu.2010.02.007] [PMID]

[36] Gifford W, Davies B, Edwards N, Griffin P, Lybanon V. Managerial leadership for nurses' use of research evidence: An integrative review of the literature. Worldviews on Evidence-Based Nursing. 2007; 4(3):126-45. [DOI:10.1111/j.17416787.2007.00095.x] [PMID]

[37] Rahmanian M, Kamali A R, Mosalanezhad H, Foroughian M, Kalani N, Hatami N, et al . [A comparative study on anxiety of medical and non-medical staff due to exposure and nonexposure to the novel coronavirus disease (Persian)]. Journal of Arak University of Medical Sciences. 2020; 23(5):710-23. [DOI:10.32598/JAMS.23.COV.3577.3]

[38] Olashore AA, Akanni OO, Oderinde KO. Neuroticism, resilience, and social support: Correlates of severe anxiety among hospital workers during the covid-19 pandemic in Nigeria and Botswana. BMC Health Services Research. 2021; 21(1):398. [DOI:10.1186/s12913-021-06358-8] [PMID] [PMCID]

[39] Schierberl Scherr AE, Ayotte BJ, Kellogg MB. Moderating roles of resilience and social support on psychiatric and practice outcomes in nurses working during the covid-19 pandemic. SAGE Open Nursing. 2021; 7:23779608211024213. [DOI:10.1177/23779608211024213] [PMID] [PMCID]

[40] Di Giuseppe M, Nepa G, Prout TA, Albertini F, Marcelli S, Orrù $G$, et al. Stress, burnout, and resilience among healthcare workers during the covid-19 emergency: The role of defense mechanisms. International Journal of Environmental Research and Public Health. 2021; 18(10):5258. [DOI:10.3390/ ijerph18105258] [PMID] [PMCID] 